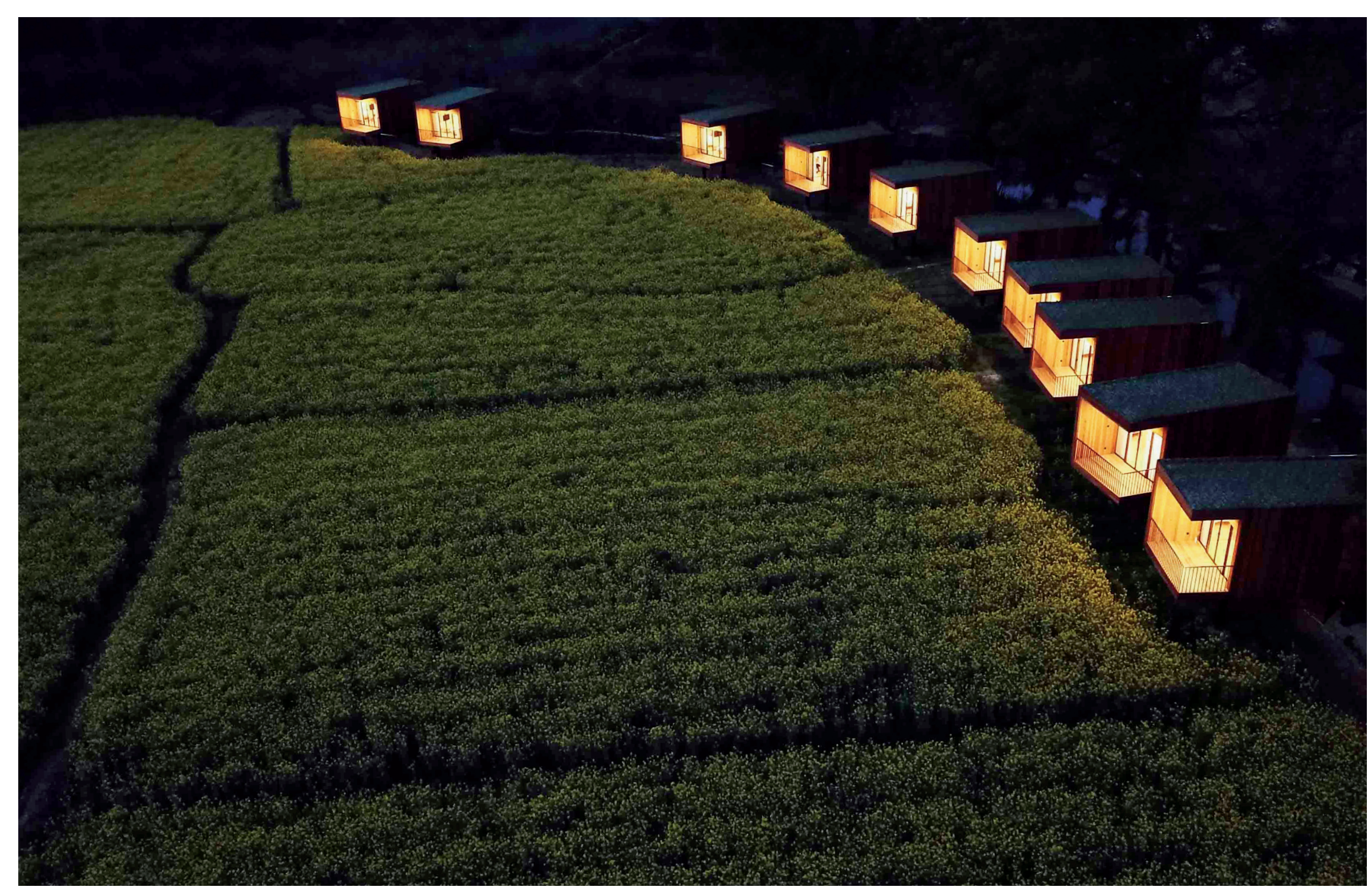


在江西省漦源县巡检司村这座偏僻的乡村中, 无人机拍摄下一片繁盛的油菜花田和 一组坐落在田埂上的组装式民宿一一这里象征着人工智能时代设计师眼中的未来乡村栖 居景观: 客人可以通过智能手机预订客房及预约其他服务; 无人驾驶汽车将客人从高铁 站接到目的地; 智能客房早在客人到来前就已调试好房间的温度; 无人机可随时将热咖 啡呈送到房门前……正如电影《头号玩家》所揭示的, 虚拟现实的景观体验无疑将充斥 智能时代的每个角落。但在影片结尾，赢得美丽虚拟世界 “绿洲” 所有权的玩家却限制 了游戏的开放时间，鼓励人们回归真实的生活场景和景观体验。因此，创造具有梦境般 体验的现实景观将成为人工智能时代颇具竞争力的领域——而景观设计师正是这样一份 面向未来的职业。

Date March 28, 2018 Location Xunjiansi Village, Wuyuan County, Jiangxi Province Photographer Jin Zhang

In Xunjiansi, a remote village in Wuyuan County, Jiangxi Province, a quadcopter photographed a rape flower field and a group of assembling homestays. The photograph suggests what future rural habitats will look like in an era of Artificial Intelligence (AI) in designers' mind. Guests can book their lodging and other services via smartphones; driverless cars will pick guests up from the high-speed train station; smart rooms will have the room temperature adjusted to guests' needs before their arriving; quadcopters can deliver hot coffee to the door whenever needed. As revealed by the movie Ready Player One, the virtual reality landscape experience will play an important role in the smart age. But at the end of the movie, to everyone's surprise, people were encouraged to return to the real life and real landscape experience by the new owner of "Oasis." So it is believed that creating reality landscapes with dreamlike experiences will be a competitive field in the age of AI - it is exactly what landscape architects' work is. 


\section{人工智能与 未来景观设计}

主编 俞孔坚

译萨拉 · 雅各布斯 张健
自18世纪60年代起, 工业革命的推进使机器做功代替了绝大部分简单的人力劳动; 到了 20 世纪 50 年代, 人类开始致力于研究用计算机代替人脑, 探索通过 “人工智能” 替代和延展 人类复杂脑力劳动的途径。半个多世纪过去了, 我们似乎已初尝胜果, 同时却也在人造的智 慧面前节节败退：1997年5月, 国际商业机器公司研发的计算机 “深蓝” 在国际象棋比赛中击 败了世界冠军加里 - 卡斯帕罗夫; 2016年3月, 谷歌旗下 “深度思维” 公司开发的 “阿尔法 狗” 在韩国首尔围棋 “人机大战” 中击败了世界冠军李世石; 2017年10月, 类人机器人 “索 菲亚” 被授予沙特阿拉伯国籍, 由此拥有了与人类同等的权利! 今天, 全球普及的无人机、投 入路试的无人驾驶汽车, 以及越来越多的无人商店和机器人服务, 正在将人类自身的就业空间 不断压缩……是喜是忧, 众说纷纭一一这和当年人们面对汽车和火车的态度别无二致! 但无论 个体或群体的态度如何, 有一点是明确的: 人工智能时代已经到来, 要么拥抱它, 要么被它所 淘汰。

作为景观设计师，我们拥抱人工智能，因为它使景观信息的采集、储存、分析变得空前高 效和准确, 我们也得以应用前所未有的方式去再现、感知和体验景观。借助高精度的无人数码 相机和空间信息处理设备, 以及功能日益强大的地理信息系统, 我们可以瞬间实现对地球上任 意偏远景观的数字化再现——这在十年前甚至都无法想象! 如今, 功能强大的计算机能够以惊 人的速度、精确度和最绚丽的表达方式将景观设计作品呈现出来, 并通过虚拟现实技术和增强 现实技术使之达到令人难以置信的真实程度, 鲜活地展现在大众和决策者面前! 仿佛是在随心 所欲地改变着地球表面!

我们拥抱人工智能, 因为它极大地解放了我们的大脑, 使设计回归于创造。大量的還辑计 算、理性分析, 以及繁重的制图和设计表达工作, 可以最大限度地交由计算机来完成。人类将 充分发挥大脑的创造性功能, 如情感表达、艺术审美和灵感触发。对于景观设计学而言, 人工 智能的出现既是机遇也是挑战, 其意味着当下景观设计师的教育和培养体系函待革新, 尤其需 要在创新设计和人机互动方面实现质的飞跃。

我们拥抱人工智能, 因为人工智能将改变我们的生活方式, 并为设计师创造更加理想的人 居环境提供潜在机遇。工业化的机器和与之相适应的灰色基础设施 (诸如大面积的停车场、巨 大的排水管道、能源供给和储存系统等), 在提供城市生活所必须的服务的同时, 也使城市景 观变得无趣、危险、丑徆、浪费! 而智能化的城市为我们改变这一现状创造了机会: 智能汽车 和新型交通系统的出现可以使停车场面积缩减至少三分之二, 马路也不必如此宽阔, 由此节省 出的土地将更多被用作城市绿地和休闲空间; 智能化的雨洪管理系统可以将大量几余的排水管 道转变为储水空间，使水资源利用更加高效和可持续……

我们拥抱人工智能, 因为它并没有湮灭人类对于景观的追求, 反而启发人们将现实景观视 作寄托人类生活理想的载体。正如电影《头号玩家》所揭示的, 虚拟现实的景观体验无疑将充 斥智能时代的每个角落。但在影片结尾, 赢得美丽虚拟世界 “绿洲” 所有权的玩家却限制了游 戏开放时间, 鼓励人们回归真实的生活场景和景观体验。因此, 创造具有梦境般体验的现实景 观将成为人工智能时代颇具竞争力的领域——就是说, 设计和创造美丽的景观将是面向未来 的重要职业。

最后, 我们拥抱人工智能, 因为在这个人工智能逐渐替代、击败甚至摧毁人类的时代, 如 果世界上只剩下最后一个人类, 那么, 这个人必定是一位设计师! 


\section{ARTIFICIAL \\ INTELLIGENCE AND \\ FUTURE LANDSCAPE ARCHITECTURE}

CHIEF EDITOR Kongjian YU

TRANSLATED BY Sara JACOBS Angus ZHANG

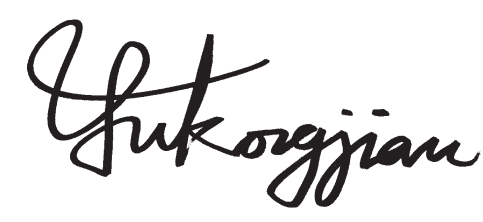

Since the 1760s, the industrial revolutions have liberated majority of human labor through machine production. By the 1950s, people started to explore how to equip Artificial Intelligence (AI) with complex cognitive function and let it do works even unachievable for human. For the past fifty years, we seem to have achieved some victory at the cost of losing ground in the face of AI, a product made by humans ourselves: In May 1997, the IBM (International Business Machines Corporation) computer Deep Blue defeated world champion Garry Kasparov in a chess game; in March 2016, the AlphaGo developed by DeepMind, a Google subsidiary, defeated world champion Lee Sedol in the Man versus Machine Go Game held in Seoul, Korea; and in October 2017, the humanoid robot "Sofia" was granted Saudi Arabian citizenship. Quadcopters, driverless cars, and other unmanned services are challenging the need for some human occupations. Should we worry about this? Worry or not, it is the same attitude people once had towards cars and trains! Regardless, one thing is clear: the age of AI has arrived and if we do not embrace it, we will only be eliminated by it.

We landscape architects embrace AI because it enables the collection, storage, and analysis of landscape information to be more efficient and accurate, and allows us to reproduce, perceive, and experience landscapes in unprecedented ways. With the help of high-precision unmanned digital cameras, spatial processing equipment, and increasingly powerful geographic information systems, we can instantaneously digitize and reproduce any remote landscape on Earth — something that was unimaginable ten years ago! Today, computers can represent newly designed landscapes with incredible speed, precision, and gorgeous expressions (by means of virtual reality and augmented reality technologies) that vividly convey design ideas to the public and decision-makers. It seems that we are changing the surface of the earth freely.

We embrace AI because it allows us to return to creation and design. Many calculations, analyses, and tedious drawing and modeling work are already being done by computers, leaving people more time on emotional expression, artistic appreciation, and brainstorming. The emergence of AI is both an opportunity and a challenge for Landscape Architecture, and the education and training of landscape architects need to introduce new forms of innovative design and human-machine interaction.

We embrace AI because the changes in lifestyle will provide opportunities for designers to create more desirable living environments. Machines as well as the supporting grey infrastructures such as parking lots, high-capacity drainage channels, and energy supply and storage systems provide services to urban life, but they also make the urban landscape boring, dangerous, ugly, and wasteful. Intelligent cities have created opportunities to change this situation. Smart cars and new transportation systems can reduce parking area by at least two-thirds and narrow the redundant roads. This will save more land for urban greenery and recreational spaces. Additionally, the intelligent stormwater management systems which creatively use redundant drainage pipelines to store water make the use of water resources more efficient and sustainable....

We embrace AI because it has not dampened our attention to landscape, but rather made us regard the reality landscape as a sustenance reflecting our desire to live. As revealed by the movie Ready Player One, the virtual reality landscape experience will play an important role in the smart age. But at the end of the movie, to everyone's surprise, people were encouraged to return to the real life and real landscape experience by the new owner of "Oasis." So it is believed that creating reality landscapes with dreamlike experiences will be a competitive field in the age of AI, and the design and creation of landscape will be one of the most important professions.

We embrace AI although in the age when AI is gradually replacing, defeating or even destroying humans That is because we believe that if there is only one human left in the world, he or she must be a designer! 